Jane Block, architecture and art librarian for the University of Illinois Library at UrbanaChampaign, has been appointed to an international jury that will determine the winner of the prize for Young Humanistic Scientists in Belgium. The goal of this prize, the only Belgian distinction awarded by the King of Belgium, is to further "the development of higher education and scientific research in Belgium." It carries an award of 100,000 Euros $(\$ 125,000)$ and is the equivalent of the Nobel Prize in the United States.

Barbara J. Ford, distinguished professor and director of the Mortenson Center for International Library Programs at the University of Illinois Library at Urbana-Champaign, has been elected to the Standing Committee of the University Libraries and Other General Research Libraries Section of the International Federation of Library Associations and Institutions (IFLA) for 2003-07.

Doris Helfer, chair of the Library Technical Services Department at California State UniversityNorthridge, was awarded the Rose L. Vormelker Award from the Special Libraries Association (SLA). This award is given in recognition of special librarianship in the area of mentoring students and/or practicing professionals in the field. She will receive the award later this year at the annual SLA Conference in Nashville, Tennessee.

Jo Kibbee, associate professor of library administration, head reference librarian at the University of Illinois Library at Urbana-Champaign, has been named to the editorial board of Reference Services Review, a quarterly journal dedicated to the enrichment of reference knowledge and the advancement of reference services.

Raymond Lum, Asian bibliographer for Harvard University's Widener Library and librarian for the Western languages collection at Harvard-Yenching Library, is the corecipient of the Carol Ishimoto

Ed. note: To ensure that your personnel news is considered for publication, write to Ann-Christe Galloway, production editor, C\&RL News, 50 E. Huron St., Chicago, IL 60611-2795; e-mail: agalloway@ala.org; fax: (312) 280-2520.

Award for Distinguished Service in the Harvard College Library. Lum has worked for the library for more than 25 years; his accomplishments include assisting with 75 th Anniversary Celebration of Harvard-Yenching Library, contributing to the exhibition catalog Treasures of the Yenching, acting as curator for the exhibition "Portraits from China 1923-1946" for the Peabody Museum, and mounting a third exhibition of East Asian ephemeral materials in the Pusey Library. Lum was also manager of a project to digitize the Hedda Morrison Photographs of China collection and is currently managing a project to digitize 1,000 photographs from the Pickens Collection on Chinese Muslim life.

Judith Mayzel, professor of library services at Oakton Community College in Des Plains, Illinois, is the winner of the North Suburban Library System Academic Library Staff Member of the Year award for 2003.

Jennifer Hain Teper, conservator for the University of Illinois Library at Urbana-Champaign, has been named one of Library Journals Movers and Shakers for 2004. This award identifies emerging leaders in the library world; each year it profiles 50 up-and-coming professionals in the United States and Canada who are innovative, creative, and making a difference in librarianship.

\title{
Appointments
}

Mary Case, director of the Association of Research Libraries (ARL) Office of Scholarly Communication (OSC), will be leaving this role to take the position of university librarian at the University of Tllinois-Chicago on July 1 . Some of her achievements include orchestrating a high-profile challenge to the anticompetitive behavior of some scientific and scholarly publishers; conceiving and developing with colleges the Create Change campaign; working

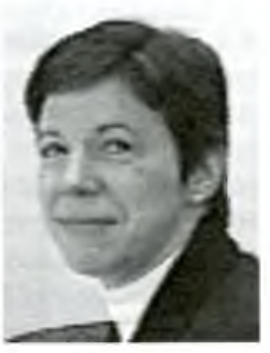

Mary Case 
with the ARL community to establish SPARC; expanding awareness through academe of scholarly communication issues; framing and sustaining constructive dialogues on intellectual property and scholarly communication issues with higher education associations, scholarly societies, and commercial publishers; coordinating teleconferences sponsored by the Shared Legal Capability on the DMCA, UCITA, and the USA PATRIOT Act; and leading the development of "Principles for Licensing Electronic Resources."

Jo Cates, library director at Columbia CollegeChicago, has been appointed to the new position of dean of the library. Cates began her professional career as reference librarian at Harvard's Lamont

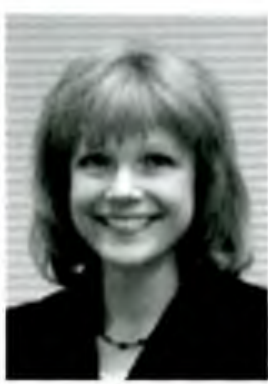

Jo Cates Library. She was founding director of the Eugene Patterson Library at the Poynter Institute for Media Studies in St. Petersburg, Florida, and also served as head of the Trans portation Libiary at Northwestern University. Prior to joining the Columbia College Chicago Library in the summer of 2001 , Cates spent four years as regional research manager at Ernst \& Young's Center for Business Knowledge. She is the author of Joumalism: A Guide to the Reference Literature $2 \mathrm{~d}$ ed. (Libraries Unlimited, 1997). The first edition was named a best reference book by Library Journal in 1990; the third edition will be published by Libraries Unlimited/Greenwood Publishing Group later this year. She also has published numerous chapters, reviews, and articles, the most recent on the new Art of the Library program at Columbia (American Libraries, July/August 2003). She created and wrote the "acKnowledge Management" column in the Business \& Finance Division Bulletin (1999-02). Cates is a member of ALA, ACRL, the Association for Education in Joumalism and Mass Communication, and the Special Libraries Association.

Thomas (Tom) M. Peischl was appointed dean of library services at Central Washington University last September, after spending ten years as chief information officer at the University of WisconsinParkside (1998-03) and dean of academic information services at Northern Michigan University (1994-98). His prior experience includes dean of

the library at Mankato State University (1984 94), director of college libraries (1979-84) and director of computer services (1981-84) at SUNY College-Potsdam, and a variety of library positions at University of Northern Colorado (1974-79) and the University of Denver

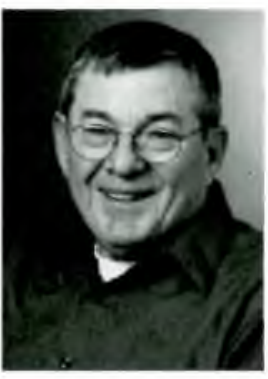

Thomas M. Peischl (1972-74). Peischl is a renewed member of ACRL, having previously served on many committees from 1981 to 1999 . He has also been active in the Library Administration and Management Association, the Council of University of Wisconsin Librarians Executive Committee (1998-2002), the Upper Peninsula Region of Library Cooperation (1994-98), and MINITEX (1986-94). Peischl has given a number of presentations throughout the years and has been published in several publications.

Carole C. Wedge has been elected president of Shepley Bulfinch Richardson and Abbott (SBRA). Wedge, who joined SBRA in 1986, was named principal in 2000 and for the past three years has served on the Board of Directors. As a senior member of the firm's Education Practice Group, Wedge has been a planner and programmer for academic buildings in higher education, including academic libraries. She is an active member of ACRL.

Donna Braquet has joined the University of Tennessee-Knoxville Libraties as life sciences librarian.

Karl Debus-Lopez has been appointed associate university librarian for collections and technical services at Georgetown University Library.

\section{Advertiser index}

$\begin{array}{lr}\text { ACM } & 209 \\ \text { Annual Reviews } & 233 \\ \text { Association of Research Libraries } & 217 \\ \text { Blackwell's Book Services } & \text { Cover } 3 \\ \text { Chemical Abstracts Services } & \text { Cover } 2 \\ \text { Choice } & 203 \\ \text { EBSCO } & \text { Cover } 4 \\ \text { Emery-Pratt } & 190 \\ \text { Intelex } & 187 \\ \text { Oxford University Press } & 213\end{array}$


Ravonne Green is now assistant professor in the MLIS program at Valdosta State University in Valdosta, Georgia.

Ksenya Kiebuzinksi has been named Petro Jacyk bibliographer for the Ukrainian Collection in the Slavic Division at the Harvard College Library.

Shoko Kreutzfeld has been named electronic resources cataloger in the Center for Information Processing at Southern Methodist University.

Mark Paul Langer is now head of acquisitions at George Washington University's Gelman Library.

Laura Maldonado has joined the Gelman Library at George Washington University as a reference and instruction librarian.

Nina McHale is now reference librarian and Web services coordinator at Georgetown University Library.

Youngjoo Moon has been named electronic resources and special formats cataloger at Georgetown University Library.

Ann O'Rahilly is now the conservation technician for the Harvard University Library in Special Collections.

Sara Pensgard has been appointed resource management librarian at Liberty University's Integrated Leaming Resource Center.

Patricia Budzinski Profeta is now the assistant dean of leaming resources at Indian River Community College in Fort Pierce, Florida.

Robert S. Willard is now strategic marketing officer and codirector of new business development at the Government Printing Office.

\section{Retirements}

Pat Henderson has retired after $301 / 2$ years as a reference librarian for Valencia Community College in Orlando.

Ellen Nagle, director of the Bio-Medical Library at the University of Minnesota since 1990 , has retired. Nagle is a distinguished member of the Academy of Health Information Professionals, Academic Library Association, Beta Phi Mu (Library Science Honorary Society); served on the editorial board of Medical Reference Services Quarterly; and was editor of "Sci-Tech Online" quarterly. She served as the principal investigator on several grants and was the author of many articles on educational initiatives in the health sciences libraries.

\section{Deaths}

Thomas J. Galvin, 71, professor emeritus at the University at Albany-SUNY, has died. Galvin joined the University at Albany in 1989 to implement the school's doctoral program in information science as its inaugural director. He also served as professor in the School of Information Science and Policy until his retirement in 1999. Galvin served as ALA executive director from 1985 through 1989. From 1974 to 1985, he was dean of the School of Library and Information Science at the University of Pittsburgh. From 1962 to 1972 , he held a series of combined faculty and administrative appointments at the Graduate School of Library and Information Science at Simmons College, culminating in his being named associate dean and professor. Galvin received many awards and honors, including the ALISE Award for Professional Contributions to Library and Information Sciences Education (1993), the Medical Library Association's Eliot Prize for the most significant contribution to the literature of medical librarianship (1988), and the best information science book of the year by the American Society for Information Science (1979). In 1980 he was appointed by the secretary of state to the U.S. National Commission on UNESCO. He was also the author, coauthor, or editor of nearly 20 books and more than 100 published articles and reports.

Toyo Suyemoto Kawakami, 87 , retired head of the Social Work Library and assistant head of the Education/Psychology Library at Ohio State University (OSU), has died. Following the bombing of Pearl Harbor, Kawakami and her family were interned at the Topaz Relocation Center, where she served as school librarian. After she was released from Topaz in 1945, Kawakami worked at the Cincinnati Museum as a reference librarian and later served approximately 13 years as reference librarian at the University of Cincinnati's College of Nursing. She joined OSU in 1958 and served the libraries for 29 years. Her scholarly works include Acromyms in Education and the Behavioral Sciences, and her more recent literary work can be found in collections such as Last Witnesses: Reflections on the Wartime Interment of Japanese Americansand Only What We Could Carry: The Japanese-American Internment Experience. Kawakami is considered a leading poet and author of the Nisei generation. 


\section{Maximize Your Holdings in 2004 With the Annual Reviews}

\section{Electronic Back Volume Collection}

Over 70 Years of Annual Reviews Content Online and Available for Purchase TODAY

Institutions can now enhance and supplement their current subscriptions with a comprehensive, fully searchable, and supplemented electronic collection of all Annual Reviews back volumes, with content spanning the Biomedical, Physical, and Social Sciences, dating back to the very first volume of the Annual Review of Biochemistry" in 1932.

The Annual Reviews Electronic Back Volume Collection takes your holdings one step further and bridges the content gap by providing access to the remaining back volumes in each Annual Reviews series to give you ALL Annual Reviews Content online and available to your patrons.

Features and Benefits Include:

- One Time Purchase - One Price - One Invoice

- Immediate Access to $875^{+}$Volumes - Over 20,000 Critical and Authoritative Review Articles from 1932-1998

- Fully Supplemented and Searchable Full-Text PDFs

- COUNTER Compliant Usage Statistics

- Single-Site and Multi-Site Licenses Available

Contact the Annual feviews Site License Department for more information or to place an ouder for your institution.

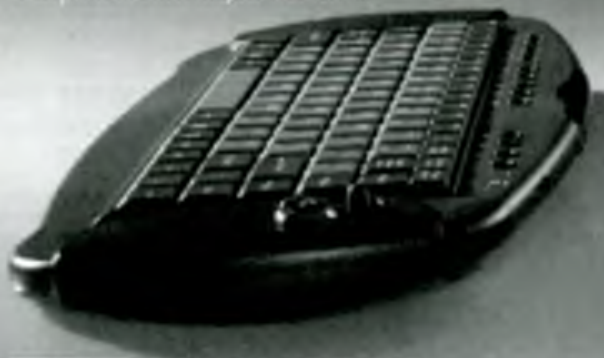

ANNUAL REVIEWS

Nonprofit Publisher of the Annual Review of 'm Series

To Reach the Annual Reviews Site License Department:

Call Toll free (US/Canada): 800.523 .8635 or Worldwide: 650.493 .4400

Email: sitelicense@annualreviews.org | www.annualreviews.org/go/crl3 